\title{
Chitosan Fiber in Textile Engineering: Advanced Dressing from a Natural Source
}

\author{
Mehrnaz Moattari $^{1}$, Farahnaz Moattari ${ }^{2}$, Gholamreza Kaka ${ }^{3 *}$, Homa Mohseni Kouchesfehani ${ }^{1 *}$, Homayoon \\ Sadraie $^{3}$ and Majid Naghdi ${ }^{4}$
}

${ }^{1}$ Department of Animal Biology, Kharazmi University, Iran

${ }^{2}$ Faculty of Agriculture and Natural Resources, Persian Gulf University, Iran

${ }^{3}$ Neuroscience Research Center, Baqiyatallah University of Medical Sciences, Iran

${ }^{4}$ Fasa University of Medical Science, Iran

Submission: July 06, 2018; Published: August 22, 2018

*Corresponding author: Mohseni Kouchesfahani H, Department of Animal Biology, Kharazmi University, Tehran, Iran, Tel: +989123844874; Fax: +982126127286; Email: homamohseni123@gmail.com

Gholamreza Kaka, Neuroscience Research Center, Baqiyatallah University of Medical Sciences, Tehran, Iran, Tel: +989123844874;

Fax: +982126127286; Email: gholamrezakakamhr@gmail.com

Abstract

Chitosan is a naturally-occurring starch (polymer) derived from the shells of crustaceans. Chitosan consists of primarily of 2-amino-2-deoxyD-glucopyranose unit linked by $\beta$-(1-4) linkage, and small amount of $\mathrm{N}$-acetyl-D-glucosamine residues. Chitosan has been found with important and wide properties in agriculture, antimicrobial field, cosmetics, food, medicine, and textile engineering. Many researches showed chitosan had antimicrobial activities on bacteria, postharvest pathogens, plant phytopathogenic fungi, yeast and virus. Here, the authors mentioned beneficial effects of chitosan-based materials in advanced wound dressings.

Keywords: Chitosan; Textile engineering; Wound dressing, Polysaccharide; Crustaceans; Diatoms sponges; Biomedical applications; Biodegradable biopolymer

\section{Introduction}

Chitin ( $\beta$-(1-4)-poly- $\mathrm{N}$-acetyl-D-glucosamine) is widely distributed in nature and is the second most abundant polysaccharide after cellulose. Chitin is often present in crustaceans, fungi, yeasts, diatoms sponges, corals, molluscs, and worms. As chitin is not readily dissolved in common solvents, it is often converted to its more deacetylated derivative, chitosan. Even though chitin and chitosan are known to have important functional activities and are used in food and biomedical applications [1]. Chitosan, derived from chitin, is composed of randomly distributed-(1-4)-linked D-glucosamine and N-acetyl-D-glucosamine (Figure 1). It is usually obtained by treating the chitin shells of shrimp and other crustaceans with sodium hydroxide. Chitosan has received considerable attention as a functional, renewable, nontoxic, and biodegradable biopolymer for diverse applications, especially in pharmaceutics, food, and cosmetics. In the medical field, chitosan has been developed not only as artificial skin and a wound healing accelerator, but also as a new physiological material due to its antitumor, immunoenhancing, and antimicrobian properties [2]. Chitosan can be gained from chitin through alkaline hydrolysis of the N-acetyl groups. Chitosan degradation occurs by nonspecific enzymes such as lysozymes, chitinases, cellulases or hemicellulases, proteases, lipases, $\beta-1,3-1,4$ glucanases as well as chitosanases.

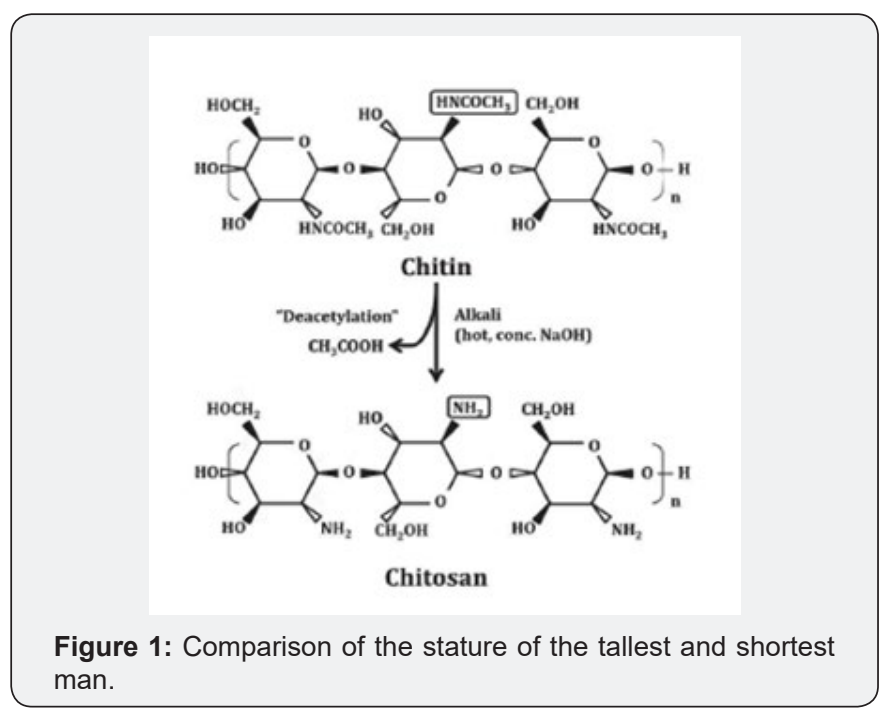




\section{Discussion}

\section{Chitosan-based materials: Advanced dressing from a natural source}

Chitin, together with its derivatives, has been shown to be useful as a wound dressing material and chitosan-based materials are an essential candidate for tissue engineering [3]. Bleeding is the number one killer on the battle field and it is crucial that all military personnel know basic first aid to stop bleeding in a combat zone. It also has other proven properties that are beneficial throughout all stages of wound healing [4]. For example, accelerates healing [4] stimulates the immune response [5], has antimicrobial (bacteriostatic and fungistatic) [6], haemostatic [7], non-toxic to the wound bed and biocompatible and biodegradable properties [3] and are effective in managing exudate [8]. Due to the extensive history of chitosan use in emergency, military, and retail first-aid, use of the Chitosan bandage is one way to control serious arterial bleeding. The chitosan bandage IS NOT used for wounds with minimal to moderate bleeding and it is recommended to be used in conjunction with a tourniquet to control severe arterial bleeding [9]. Due to its absorbent properties, chitosan locks fluid within its core, reducing the lateral wicking action seen in other exudate management dressings. Chitosan also has an accelerating effect on wound healing [10] by activating immune cells through its cytokine production, giant cell migration, and stimulating type IV collagen synthesis [11]. The positive charge of chitosan fibers also enables them to halt bleeding by binding to negatively charged red blood cells, resulting in faster coagulation. By polymerizing with blood to form a net-like structure, the fibers further capture red blood cells leading to clotting. Also, some researches approved the positive charge of - $\mathrm{NH} 2$ groups of chitosan has main contribution to the antimicrobial activity. In fact, chitosan works by creating a positive charge, hence interacting with negatively charged molecules such as gram positive bacteria, blood cells, proteins and lipids [12]. Research showed that whole blood formed a coagulum rapidly upon exposure to chitosan the results of the blood coagulation time (BCT) showed that chitin and chitosan reduced BCT significantly in a dose-dependent manner, and they enhanced the release of the platelet derived growth factor- $\mathrm{AB}$ (PDGF-AB) and the transforming growth factor- $\beta 1$ (TGF- $\beta$ 1) from the platelets, particularly with chitosan [13].

\section{Conclusion}

The use of chitosan-based materials in wound dressing has arisen as a research focus in the past two decades. Here, we introduce the roles of chitosan-based constituents as a natural biomaterial in treating one of the complications in human life.

\section{Acknowledgement}

We thank Prof. Hedayat Sahraei \& Dr. Boshra Hatef because of kind considerations.

\section{References}

1. Santos-Moriano P, Fernandez-Arrojo L, Mengibar M, Belmonte-Reche E, Peñalver P, et al. (2018) Enzymatic production of fully deacetylated chitooligosaccharides and their neuroprotective and anti-inflammatory properties. Biocatal Biotransformation 36(1): 57-67.

2. Kim SK, Abe S, Ishihara K, Adachi M, Ahn BN, et al. (2018) Antioxidant effects of phlorotannins isolated from Ishige okamurae in free radical mediated oxidative systems. In: Healthcare Using Marine Organisms. Springer Boca Raton, FL, USA, pp. 1-6.

3. Moattari M, Kouchesfehani HM, Kaka G, Sadraie SH, Naghdi M, et al. (2018) Chitosan-film associated with mesenchymal stem cells enhanced regeneration of peripheral nerves: A rat sciatic nerve model. J Chem Neuroanat 88: 46-54.

4. Hamedi H, Moradi S, Hudson SM, Tonelli AE (2018) Chitosan Based Hydrogels and Their Applications for Drug Delivery in Wound Dressings: A Review. Carbohydr Polym.

5. Ding F, Li H, Du Y, Shi X (2018). Recent advances in chitosan-based selfhealing materials. Res Chem Intermed: 4827-4840.

6. Moattari M, Kouchesfehani HM, Kaka G, Sadraie SH, Naghdi M (2018) Evaluation of nerve growth factor (NGF) treated mesenchymal stem cells for recovery in neurotmesis model of peripheral nerve injury. J Craniomaxillofac Surg 46(6): 898-904.

7. Lee EJ, Huh BK, Kim SN, Lee JY, Park CG, et al. (2017) Application of materials as medical devices with localized drug delivery capabilities for enhanced wound repair. Prog Mater Sci 89: 392-410.

8. Vidyavathi M, Farhana SKM, Sreedevi A (2018) Design and Evaluation of Lentil Seed Extract Loaded Bio Scaffolds for Wound Healing Activity. Biomed Pharmacol J 11(1): 503-511.

9. Boroff KE, Boroff A (2018) Performance management-making a difference? Case J 14(1): 25-53.

10. Yegappan R, Selvaprithiviraj V, Amirthalingam S, Jayakumar R (2018) Carrageenan based hydrogels for drug delivery, tissue engineering and wound healing. Carbohydr Polym.

11. Mezzana P (2008) Clinical efficacy of a new chitin nanofibrils-based gel in wound healing. Acta Chir Plast 50(3): 81-84.

12. Niekraszewicz A (2005) Chitosan medical dressings. Fibres Text East Eur 13(6): 54.

13. Zhang J, Xia W, Liu P, Cheng Q, Tahi T, et al. (2010) Chitosan modification and pharmaceutical/biomedical applications. Mar Drugs 8(7): 19621987. 
CC (i) This work is licensed under Creative Commons Attribution 4.0 Licens

DOI: 10.19080/CTFTTE.2018.04.555634

\section{Your next submission with Juniper Publishers will reach you the below assets}

- Quality Editorial service

- Swift Peer Review

- Reprints availability

- E-prints Service

- Manuscript Podcast for convenient understanding

- Global attainment for your research

- Manuscript accessibility in different formats

( Pdf, E-pub, Full Text, Audio)

- Unceasing customer service

Track the below URL for one-step submission https://juniperpublishers.com/online-submission.php 